\title{
GAYA BAHASA ASONANSI DALAM CATATAN HARIAN CATATAN NAJWA KARYA NAJWA SHIHAB
}

\author{
Firman Tara ${ }^{1}$, Asiho Pama Mailani $\mathbf{H}^{2}$ \\ Program Studi Pendidikan Bahasa dan Sastra Indonesia, \\ Fakultas Keguruan dan Ilmu Pendidikan, Universitas Batanghari, \\ Jambi
}

firmantara14@gmail.com

asihopama81@gmail.com

\begin{abstract}
The purpose of the research is to describe the assonance figurative language in Catatan Harian Catatan Najwa by Najwa Shihab. The data of this research is primary data which consists of quotations of assonance figurative language and the metaphor of that assonance. The source of this data is daily notes of Catatan Najwa by Najwa Shihab. This research is qualitative with descriptive method. Through collecting data, choosing data, and analyzing data, the research can understand the assonance figurative language and the metaphor from the daily notes of Catatan Najwa by Najwa Shihab. Moreover, the researcher interpreted it logically and drawed the conclusion for each discussion.The result shows that there are three things that are related to this research, they are two kinds of assonance figurative language; assonance figurative language of vowel repetition on one speech and one line. For example: Indonesia adalah kata kerja, kita semua yang harus menuntaskannya. Next is assonance figurative language with the repetition of vowel pattern on two lines, such as: Cukup lama dia geming membatuMenyindir kekuasaan yang penuh ragu. Moreover, there are some words that comprise metaphor, such as: Uluran tangan which means giving help, geming membatu which means being silent without saying any words, ibu pertiwi which means Indonesia land, which is suitable with this theory (Suwandi, 2011: 117). Thus, it can be concluded that there are two kinds of assonance figurative language and words that have metaphor meaning in Catatan Najwa daily notes.
\end{abstract}

Keywords: Assonance Figurative Language, Assonance Figurative Language, Metaphor, Daily Notes

1 Dosen Program Studi Pendidikan Bahasa dan Sastra Indonesia, Fakultas Keguruan dan Ilmu Pendidikan, Universitas Batanghari, Jambi

2 Mahaisiswa Program Studi Pendidikan Bahasa dan Sastra Indonesia, Fakultas Keguruan dan Ilmu Pendidikan, Universitas Batanghari, Jambi 


\section{PENDAHULUAN}

Bahasa merupakan deretan bunyi bersistem yang digunakan sebagai alat untuk berkomunikasi (Pateda, 1994: 6). Bahasa selalu berkaitan erat dengan karya sastra. Hal tersebut dikarenakan karya sastra ditulis dengan menggunakan bahasa, yang di dalamnya terdapat lambang bunyi bermakna, sehingga karya sastra dapat dijadikan sebagai objek kajian penelitian bahasa, dalam penelitian ini penulis akan meneliti penelitian bahasa yang mengkaji sebuah karya sastra non-imajinatif.

Sastra terdiri dari dua jenis, yaitu sastra imajinatif dan sastra nonimajinatif. Sastra imajinatif adalah sastra yang diciptakan berdasarkan imajinasi pengarang, sedangkan sastra nonimajinatif adalah sastra yang diciptakan berdasarkan fakta atau kenyataan yang terjadi sebenarnya yang dituangkan dengan gaya bahasa.

Karya sastra merupakan karya yang diciptakan seseorang tentang segala hal yang berhubungan dengan manusia dan segala permasalahan kehidupannya secara lengkap. Kehidupan manusia tidak terlepas dari berbagai masalah. Masalah yang dihadapi pun beraneka ragam, mulai dari masalah kecil hingga masalah yang rumit. Tidak jarang, seseorang yang mengalami suatu kejadian yang berasal dari pengalaman pribadinya ataupun berdasarkan pengalaman kehidupan orang lain yang ada di sekitarnya ditulis ke dalam sebuah karya sastra, yaitu dalam bentuk catatan harian yang merupakan bagian dari sastra nonimajinatif.

Menurut pengamatan penulis, saat ini penulisan catatan harian sudah mulai menurun, anak muda saat ini banyak yang menuangkan setiap permasalahannya baik yang positif maupun negatif melalui status di media sosial sehingga seringkali dapat menimbulkan pertengkaran, padahal alangkah lebih baiknya jika kita menuliskan setiap apa yang kita rasakan dalam bentuk tulisan dengan media buku, dengan menggunakan bahasa pilihan, sehingga tulisan tersebut dapat menjadi teladan bagi para pembacanya, berdasarkan uraian di atas penulis tertarik untuk mengkaji gaya bahasa asonansi dalam catatan harian. Kutipan makna kiasan yang terdapat dalam catatan harian catatan Najwa, yaitu mereka hadapi persoalan rakyat kecil, dengan hasil rill lewat kerja-kerja detil, rakyat kecil kata yang digunakan bukan untuk menyebutkan rakyat yang berbadan kecil, tetapi ditujukan untuk seseorang yang memiliki perekonomian menengah ke bawah dan dikiaskan dengan rakyat kecil sehingga terdengar lebih lembut.

Gaya bahasa adalah bahasa indah yang digunakan untuk meningkatkan efek dengan jalan memperkenalkan serta membandingkan suatu benda atau hal tertentu dengan benda atau hal lain yang lebih umum. Menurut (Keraf, 1984: 113) "Gaya bahasa adalah cara mengungkapkan pikiran melalui bahasa secara khas yang memperlihatkan jiwa dan kepribadian pemakai bahasa tersebut". Salah satu bagian gaya bahasa adalah gaya bahasa retoris, gaya bahasa yang berdasarkan langsung tidaknya makna, yang di dalamnya terdapat gaya bahasa asonansi. Menurut (Keraf 1984: 130) asonansi merupakan gaya bahasa yang biasanya digunakan dalam puisi untuk memperoleh suatu efek penekanan atau bahkan sekedar untuk keindahan yang berwujud perulangan bunyi vokal yang sama.

Mata Najwa adalah program gelar wicara yang dipandu oleh jurnalis senior, Najwa Shihab. Najwa Shihab merupakan seorang jurnalis yang dipercaya untuk mengelola program mingguan. Selain menjadi jurnalis, Najwa Shihab juga ditunjuk oleh Perpustakaan Nasional Republik Indonesia untuk menjadi Duta 
Baca Indonesia (2016-2020), yaitu dengan tugas untuk menyebarkan minat membaca ke penjuru negeri. Najwa telah mewawancarai banyak sekali tokoh penting dalam dan luar negeri pada berbagai momen krusial. Ia secara khusus mewawancarai seluruh kandidat presiden dan wakil presiden pada setiap pemilu langsung di Indonesia, dari tahun 2004 hingga 2014 (Shihab, 2017: 183).

Selain terdapat siaran di TV, Najwa Shihab menulis sebuah catatan harian yang menjadi best seller, buku cetakan ketiga dari Najwa Shihab ini berjudul Catatan Najwa yang dipublikasikan pada Februari 2017. Buku Catatan Najwa ini berisikan refleksi Najwa Shihab atas isu yang dibahas di program Mata Najwa dengan gaya, rima yang khas, Catatan Najwa menggelitik dengan sindiran yang menohok tajam, yang akan terus relevan dibaca kapan pun. Buku Catatan Najwa ini terdapat 50 tema, dari sejumlah tamu yang telah hadir dan berbicara di Mata Najwa di antaranya ialah Presiden ke-3 RI, Bacharuddin Jusuf Habibie (episode: Habibie dan Suara Anak Negeri), Presiden ke-5 RI Megawati Soekarno Putri (episode: Apa Kata Mega), Mantan Wakil Presiden Boediono (episode: Di Balik Diam Boediono). Kutipan gaya bahasa asonansi yang terdapat dalam catatan harian Catatan Najwa seperti Indonesia adalah kata kerja, kita semua yang harus menuntaskannya dengan bunyi vokal /a/ (Shihab, 2017: 003), Di kala partai ramai-ramai berkoalisi dengan vokal, Megawati sedikit dari yang tak terbeli (Shihab, 2017: 007) dengan bunyi vokal $/ i /$.

Dari uraian di atas dapat disimpulkan bahwa antara bahasa dan karya sastra memiliki hubungan erat, bahasa dan karya sastra saling berkaitan. Seseorang dapat menuliskan suatu karyanya baik secara imajinatif maupun non-imajinatif, seperti Catatan Najwa ini yang ditulis dengan bentuk sastra nonimajinatif. Adapun tulisan yang terdapat dalam Catatan Najwa ini ditulis dengan menggunakan gaya bahasa asonansi, yaitu dengan memasukkan unsur keindahan dengan perulangan bunyi vokal yang sama, dan menggunakan makna kiasan yang diungkapkan langsung oleh Najwa Shihab dengan gaya yang khas.

Adapun alasan penulis untuk meneliti gaya bahasa asonansi dalam Catatan Najwa karya Najwa Shihab, pertama yaitu penulis tertarik mengkaji gaya bahasa karena gaya bahasa dapat memperlihatkan kepribadian penulisnya, seorang penulis menulis dengan gayanya sendiri. Kedua, penulis tertarik untuk meneliti gaya bahasa asonansi yang terdapat dalam Catatan Najwa karena didalam catatan tersebut banyak ditemukan gaya bahasa asonansi. Ketiga, penulis tertarik untuk meneliti Catatan Najwa karena selain catatan tersebut diisi oleh tokoh penting, catatan tersebut berisikan refleksi Najwa Shihab atas isu yang dibahas di program Mata Najwa dengan gaya, rima yang khas, dengan penyampaian Najwa yang bukan seperti catatan biasa, tetapi catatan yang ketika dibaca seperti membaca puisi, yang dapat pula dijadikan pedoman hidup bagi penulis, dan Catatan Najwa ini merupakan catatan yang menjadi best seller.

Berdasarkan paparan di atas adanya keunikan yang disampaikan oleh Mata Najwa tidak hanya dalam bentuk acara talkshow tetapi juga dalam catatan hariannya, sehingga penulis tertarik untuk melakukan kajian tentang gaya bahasa asonansi dalam catatan harian Catatan Najwa dengan alasan:

1. Gaya bahasa dapat memperlihatkan bagaimana jiwa dan kepribadian penulisnya, sehingga gaya bahasa itu unik. 
2. Gaya bahasa asonansi banyak terdapat dalam catatan tersebut, yaitu dengan menggunakan gaya bahasa yang berwujud perulangan bunyi vokal yang sama baik pengulangan vokal dalam satu pengucapan bahasa dalam satu baris yang sama maupun pengulangan pola vokal dalam dua baris sajak, yang ketika dibaca terdengar indah.

3. Makna kiasan yang terdapat dalam catatan tersebut, menggunakan bahasa kias dengan arti yang bukan sebenarnya, sehingga dapat memperhalus sebuah ujaran.

4. Catatan harian bermanfaat sebagai media tulis yang dapat menyadarkan penulis ataupun pembacanya akan makna kehidupan yang terdapat dalam catatan harian.

5. Catatan Najwa menjadi catatan yang best seller, berisikan refleksi Najwa Shihab atas isu yang dibahas di program Mata Najwa dengan gaya, rima yang khas.

Saat ini banyak peneliti yang meneliti gaya bahasa, seperti gaya bahasa hiperbola, personifikasi dan lainnya. Padahal masih banyak sekali jenis gaya bahasa lain yang belum pernah diteliti. Bahkan, sepengetahuan penulis bahwa rata-rata peneliti di FKIP Unbari meneliti gaya bahasa dalam karya sastra dengan kajian seperti novel. Sehingga, penulis memutuskan meneliti Catatan Najwa ini karena menurut pengamatan penulis sebagai mahasiswa Program Studi Pendidikan Bahasa dan Sastra Indonesia di FKIP Unbari belum pernah diteliti, dan penulis memilih untuk meneliti gaya bahasa asonansi dan makna kias dalam catatan harian Catatan Najwa.

Berdasarkan uraian latar belakang masalah di atas, maka teridentifikasi penelitian gaya bahasa asonansi dalam catatan Harian Catatan Najwa, dapat ditinjau dari berbagai aspek, di antaranya adalah:
1. bentuk gaya bahasa asonansi dalam catatan harian Catatan Najwa karya Najwa Shihab;

2. makna gaya bahasa asonansi dalam catatan harian Catatan Najwa karya Najwa Shihab;

3. fungsi gaya bahasa asonansi dalam catatan harian Catatan Najwa karya Najwa Shihab, dan

4. tujuan gaya bahasa asonansi dalam catatan harian Catatan Najwa karya Najwa Shihab.

Berdasarkan identifikasi di atas maka penulis membatasi penelitian ini. Batasan penelitian ini penulis lakukan sehubungan dengan keterbatasan penulis dari segi waktu, kemampuan, kesempatan, maka penelitian ini menganalisis dua hal sebagai berikut.

1. Bentuk gaya bahasa asonansi dalam catatan harian Catatan Najwa.

2. Makna kiasan gaya bahasa asonansi dalam catatan harian Catatan Najwa.

Fokus penelitian merupakan sesuatu yang sangat penting, agar penelitian menjadi lebih jelas. Berdasarkan latar belakang yang telah dipaparkan, maka fokus penelitian ini adalah, "Bentuk gaya bahasa asonansi dan makna kiasan yang terdapat dalam gaya bahasa asonansi dalam catatan harian Catatan Najwa".

Berdasarkan fokus penelitian di atas maka pertanyaan penelitian ini adalah sebagai berikut.

1. Bagaimanakah bentuk gaya bahasa anonansi dalam catatan harian Catatan Najwa?

2. Bagaimanakah makna kiasan gaya bahasa asonansi dalam catatan harian Catatan Najwa?

Berdasarkan

pertanyaan penelitian di atas maka tujuan penelitian ini adalah untuk mendeskripsikan:

1. Bentuk gaya bahasa asonansi dalam catatan harian Catatan Najwa. 
2. Makna kiasan yang terdapat dalam gaya bahasa asonansi dalam catatan harian Catatan Najwa.

Berdasarkan tujuan penelitian, maka penelitian ini diharapkan dapat memberi manfaat kepada berbagai pihak. Terdapat dua macam manfaat yaitu, manfaat teoretis dan manfaat praktis yang dapat ditarik dalam penelitian ini.

Manfaat teoretis adalah manfaat yang berkaitan dengan keilmuan. Secara teoretis hasil penelitian ini diharapkan bermanfaat untuk menambah pemahaman di bidang kebahasaan khususnya dalam mengapresiasi gaya bahasa asonansi dan makna kiasan. Selain itu, penelitian ini juga dapat menambah ilmu pengetahuan tentang bahasa terutama tentang gaya bahasa asonansi.

Secara praktis, hasil penelitian dapat bermanfaat bagi :

1. Pembaca, penelitian ini dapat dijadikan sebagai ilmu pengetahuan dan dapat menambah wawasan dibidang kebahasaan pada gaya bahasa asonansi dan makna kiasan, khususnya tentang gaya bahasa asonansi dalam karya sastra nonimajinatif.

2. Guru, sebagai alternatif bahan ajar untuk materi pembelajaran bahasa Indonesia, terutama yang menyangkut tentang gaya bahasa dan makna.

3. Siswa, untuk mempermudah dan dapat memahami gaya bahasa dan makna.

4. Peneliti berikutnya, yaitu agar hasil penelitian ini dapat dijadikan referensi untuk melaksanakan penelitian yang sama dengan kajian yang berbeda dengan yang penulis lakukan agar lebih baik.

5. Penulis, penelitian ini menambah wawasan penulis mengenai gaya bahasa dan khususnya untuk gaya bahasa asonansi, serta makna kiasan.

\section{METODE PENELITIAN}

Jenis penelitian merupakan cara ilmiah untuk mendapatkan data dalam penelitian dengan maksud untuk mencapai tujuan tertentu. Seorang peneliti dapat memilih jenis penelitian yang akan digunakan. "Penelitian ilmiah merupakan penelitian yang sistematis, terkontrol, empiris, dan kritis terhadap proposisi-proposisi hipotesis tentang hubungan yang diperkirakan terdapat antar gejala alam" (Kerlinger dalam Muhammad, 2011: 28). Dalam penelitian sastra terdapat beberapa sudut pandang atau pendekatan. Perbedaan sudut pandang ini kemudian memunculkan adanya berbagai jenis penelitian sastra. Oleh karena itu, jenis penelitian tergantung dari sudut pandang atau pendekatan mana yang dipakai peneliti ( Rahima 2017: 1).

$$
\text { "Penelitian sebagai }
$$

pencarian atas sesuatu secara sistematik dengan penekanan bahwa pencarian itu dilakukan terhadap masalah-masalah yang dapat dipecahkan" (Whitney dalam Danim, 2002: 26). Peneliti melakukan sebuah penelitian untuk mendapatkan sebuah data yang akan digunakan sebagai bahan yang akan diteliti untuk memecahkan sesuatu yang menjadi pokok permasalahan. Dalam penelitian sastra terdapat beberapa sudut pandang atau pendekatan. Perbedaan sudut pandang ini kemudian memunculkan adanya berbagai jenis penelitian sastra (Rahima, 2017: 1). Berdasarkan pendapat tersebut, dapat disimpulkan bahwa jenis penelitian tergantung dari sudut pandang atau pendekatan apa yang digunakan peneliti. Terkait hal itu, menurut Gunawan, Rahima, dan Supriyati (2018: 133) jenis penelitian merupakan cara kerja suatu penelitian yang dipilih seorang peneliti dalam memahami objek penelitiannya. Jenis penelitian erat kaitannya dengan metode.

Berdasarkan pendapat tersebut maka jenis penelitian yang digunakan 
dalam penelitian ini adalah deskriptif kualitatif. Pendekatan dan metode tersebut digunakan untuk mendeskripsikan bagaimana bentuk gaya bahasa asonansi dan makna kiasan gaya bahasa asonansi dalam catatan harian Catatan Najwa. "Penelitian kualitatif bersifat deskriptif, yaitu data yang terkumpul berbentuk kata-kata, gambar bukan angka-angka. Kalaupun ada angka-angka, sifatnya hanya sebagai penunjang. Data yang diperoleh meliputi transkip interviu, catatan lapangan, foto, dokumen pribadi dan lain-lain" (Danim, 2002: 51).

"Metode kualitatif sebagai prosedur penelitian yang menghasilkan data deskriptif berupa kata-kata tertulis atau lisan dari orang-orang dan perilaku yang dapat diamati" (Bogdan dan Taylor dalam Muhammad, 2011: 30). Metode kualitatif bertujuan untuk memahami fenomena-fenomena sosial. Salah satu fenomena yang dapat menjadi objek penelitian kualitatif ialah peristiwa komunikasi atau berbahasa yang melibatkan tuturan, peristiwa tutur, tindak tutur, dan latar tutuan. Metode deskriptif pada umumnya dilakukan dengan tujuan utama, yaitu menggambarkan secara sistematis fakta dan karakteristik objek yang diteliti. Metode deskriptif ini dapat dijadikan sebagai metode penelitian khususnya penelitian yang bersifat kualitatif."

Data di dalam penelitian diperlukan data dan sumber data sebagai bahan dari suatu penelitian. Untuk melakukan penelitian seorang peneliti harus memiliki sumber data, yang akan menjadi bahan suatu penelitian. Penelitian juga harus tahu data seperti apa yang digunakan dalam penelitiannya.

Data merupakan hal yang pokok dan yang harus ada dalam suatu penelitian. "Data merupakan bagian dari pembuktian. Data harus relevan dengan pembahasan masalah" (Widjono, 2007:
247). Dalam penelitian ini data dapat dibagi menjadi dua, yakni data primer dan data skunder.

Data primer merupakan data utama di dalam penelitian. "Data primer adalah bukti penulisan yang diperoleh di lapangan yang dilakukan secara langsung oleh penulisnya" (Widjono, 2007: 248). Data primer dalam penelitian ini berupa kutipan gaya bahasa asonansi dan makna kiasan dalam catatan harian Catatan Najwa karya Najwa Shihab.

Data skunder data pendukung yang terdapat di dalam penelitian. "Data skunder adalah bukti teoretik yang diperoleh melalu studi pustaka" (Widjono, 2007: 248). Data skunder dalam penelitian diperoleh dari studi pustaka, dan buku-buku yang berkaitan dengan teori yang berhubungan dengan permasalahan yang menjadi objek penelitian.

Sumber data dalam penelitian ini adalah catatan harian Catatan Najwa karya Najwa Shihab, yang memiliki sampul luar berwarna merah darah dan bergambar setengah dari wajah sang penulis yaitu Najwa. Penulisan judul sampul berwarna putih, terdapat 208 halaman, ukuran buku $19 \mathrm{~cm}$, ditulis oleh Najwa, diterbitkan oleh Literati cetakan ketiga pada tahun 2017. Sumber data lain dalam penelitian ini adalah buku-buku yang penulis dapat dari toko-toko buku, dan perpustakaan.

Pengumpulan data menjadi satu hal yang sangat penting dalam sebuah penelitian. "Pengumpulan data adalah prosedur yang sistematis dan standar untuk memperoleh data yang diperlukan" (Nazir, 2005: 174). "Dokumentasi merupakan proses pembuktian yang didasarkan atas jenis sumber apa pun, baik itu bersifat tulisan, lisan, gambaran, atau arkeologi” (Gunawan, 2015: 175). Teknik pengumpulan data penelitian ini menggunakan teknik dokumentasi yang difokuskan dalam menganalisis gaya 
bahasa asonansi dan makna kiasan gaya bahasa asonansi dalam catatan harian Catatan Najwa karya Najwa Shihab.

Langkah-langkah pengumpulan data tetang bentuk campur kode dalam novel Senior karya Eko Ivano Winata:

1. Penulis membaca seluruh isi catatan karya Najwa Shihab yang berjudul Catatan Najwa dengan berulangulang. Dengan demikian, penulis dapat memahami data secara mendalam tentang bentuk gaya bahasa asonansi dan makna kiasan yang terdapat dalam catatan harian Catatan Najwa.

2. Penulis membubuhkan tanda dengan menggunakan pensil bagian-bagian yang berhubungan dengan gaya bahasa asonansi dan mencatat katakata yang terdapat makna kiasan dalam catatan harian Catatan Najwa.

3. Setelah data terkumpul, penulis kemudian mengklasifikasikan data sesuai dengan bentuk gaya bahasa asonansi dan makna kiasan dalam catatan harian Catatan Najwa.

Teknik analisis data merupakan langkah selanjutnya yang dilakukan peneliti setelah seluruh data terkumpulkan. Menurut Bogdan (dalam Sugiyono, 2007: 335), Analisis data adalah proses mencari dan menyusun secara sistematis data yang diperoleh dari hasil wawancara, catatan lapangan, dan dokumentasi, dengan cara mengorganisasikan data ke dalam kategori, menjabarkan ke dalam unitunit, melakukan sintesa,menyusun ke dalam pola, memilih mana yang penting dan yang akan dipelajari, dan membuat kesimpulan sehingga mudah dipahami oleh diri sendiri maupun orang lain.

Selanjutnya, menurut Miles dan Huberman dalam Sugiyono (2007: 337) mengatakan bahwa aktivitas dalam analisis data, yaitu data reducation, data display, dan drawing/verification.
Aktivitas dalam analisis data dilakukan dengan langkah-langkah:

\section{Data Reducation}

Meredukasi data berarti merangkum, memilih hal-hal yang pokok, memfokuskan pada hal-hal yang penting, dicari tema dan polanya. Dengan demikian, data yang telah diredukasi akan memberikan gambaran yang telah lebih jelas dan mempermudah penenulis untuk melakukan pengumpulan data selanjutnya dan mencari bila diperlukan.

2. Data Display (penyajian data)

Setelah data direduksi, maka langkah selanjutnya adalah penyajian data. Penyajian data ini dapat dilakukan dalam bentuk tabel, grafik, pictogram, dan sejenisnya. Melalui penyajian data tersebut, maka data terorganisasikan.

\section{Concluasion Drawing/Verification}

Langkah ketiga dalam analisis data kualitatif menurut Miles dan Huberman adalah penarikan kesimpulan dan verifikasi. Kesimpulan awal akan berubah jika tidak ditemukan bukti-bukti yang mendukung pada tahap pengumpulan data. Tetapi apa bila kesimpulan awal di dukung oleh buktibukti yang valid dan konsisten saat pengumpulan data, maka kesimpulan yang dikemukakan merupakan kesimpulan yang kredibel.

\section{HASIL DAN PEMBAHASAN}

Berikut ini akan dijelaskan hasil penelitian terkait gaya bahasa asonansi dalam catatan harian Catatan Najwa karya Najwa Shihab, dengan mendeskripsikan bentuk-bentuk gaya bahasa asonansi dan makna kiasan yang terdapat dalam gaya bahasa asonansi. Data penelitian ini diambil dari catatan harian Catatan Najwa karya Najwa Shihab. Pembahasan penelitian ini berupa pendeskripsian bentuk gaya bahasa asonansi dan makna kiasan dalam catatan harian Catatan Najwa karya Najwa Shihab. Adapun yang didapat dalam hasil 
penelitian mengenai bentuk gaya bahasa asonansi dalam catatan harian Catatan Najwa ialah gaya bahasa asonansi dengan bentuk pengulangan vokal yang sama dalam satu pengucapan bahasa dalam satu baris yang sama, dan kedua bentuk gaya bahasa asonansi dengan bentuk pengulangan pola vokal yang sama dalam dua baris sajak.

a. Gaya Bahasa Asonansi Perulangan Vokal yang Sama dalam Satu Pengucapan Bahasa dalam Satu Baris yang Sama dalam catatan harian Catatan Najwa

Gaya bahasa asonansi menjadi bagian dari gaya bahasa yang berdasarkan langsung tidaknya makna. Gaya bahasa asonansi merupakan pengulangan bunyi vokal yang sama. Asonansi merupakan perulangan vokal dalam satu pengucapan bahasa, yang biasanya terdapat dalam satu baris sajak (Junus, 1989: 215). Gaya bahasa asonansi dapat ditemukan dalam puisi atau prosa dengan tujuan untuk memperoleh efek penekanan atau untuk keindahan (Keraf, 1984: 130). Dalam penelitian ini peneliti mengambil 3 kutipan dari 270 kutipan tersebut untuk dianalisis. Bentuk 3 kutipan gaya bahasa asonansi bentuk pengulangan vokal yang sama dalam satu pengucapan bahasa dalam satu baris yang sama dalam catatan harian Catatan Najwa karya Najwa Shihab sebagai berikut.

1. Kita semua saudara sebangsa.

2. Berani bernegosiasi demi konsesi untuk negeri.

3. Kami ragu, karena semua sudah tahu .

Dalam kutipan (1) terdapat

bentuk gaya bahasa asonansi. Bentuk gaya bahasa asonansi di atas merupakan gaya bahasa asonansi dengan bentuk pengulangan vokal yang sama dalam satu kata dalam satu baris yang sama. Kalimat di atas dapat dianalisis dari penggunaan bunyi vokal yang sama pada kata dalam satu baris yang sama. Pengulangan vokal /a/ ditemukan dalam satu baris yang sama, yang dapat memberikan penekanan bunyi, sehingga ketika dibaca bunyi tersebut dapat terdengar dengan indah. Pengulangan vokal $/ a /$ ditemukan dalam satu baris yang sama, yang dapat memberikan penekanan bunyi, sehingga ketika dibaca bunyi tersebut dapat terdengar dengan indah. Pengulangan vokal $/ a /$ hampir ditemukan disetiap kata. Pengulangan bunyi vokal $/ a /$ yaitu pada kata 'kita', 'semua', 'saudara', dan 'sebangsa' yang memiliki pengulangan bunyi vokal yang sama-sama berada diakhir kata. Pengulangan vokal tersebut sesuai dengan teori Junus (1989: 215) asonansi merupakan perulangan vokal dalam satu pengucapan bahasa, yang biasanya terdapat dalam satu baris sajak.

Pada kutipan (2) terdapat bentuk gaya bahasa asonansi. Bentuk gaya bahasa asonansi di atas merupakan gaya bahasa asonansi dengan bentuk pengulangan vokal yang sama dalam satu kata dalam satu baris yang sama. Pengulangan vokal / $i /$ ditemukan dalam satu baris yang sama, yang dapat memberikan penekanan bunyi, sehingga ketika dibaca bunyi tersebut dapat terdengar dengan indah. Pengulangan vokal /i/ hampir ditemukan disetiap kata. Pengulangan bunyi vokal /i/ yaitu pada kata 'berani', 'bernegosiasi', 'demi', 'konsesi', dan 'negeri' yang memiliki pengulangan bunyi vokal yang samasama berada diakhir kata. Pengulangan vokal tersebut sesuai dengan teori Junus (1989: 215) asonansi merupakan perulangan vokal dalam satu pengucapan bahasa, yang biasanya terdapat dalam satu baris sajak.

Pada kutipan (3) terdapat bentuk gaya bahasa asonansi. Bentuk gaya bahasa asonansi di atas merupakan gaya bahasa asonansi dengan bentuk pengulangan vokal yang sama dalam satu kata dalam satu baris yang sama. Pengulangan vokal $/ u /$ ditemukan dalam 
satu baris yang sama, yang dapat memberikan penekanan bunyi, sehingga ketika dibaca bunyi tersebut dapat terdengar dengan indah. Pengulangan vokal $/ u$ / hampir ditemukan disetiap kata. Pengulangan bunyi vokal $/ u /$ yaitu pada kata 'ragu' dan 'tah $\boldsymbol{u}$ ' yang memiliki pengulangan bunyi vokal yang samasama berada diakhir kata. Pengulangan vokal tersebut sesuai dengan teori Junus (1989: 215) asonansi merupakan perulangan vokal dalam satu pengucapan bahasa, yang biasanya terdapat dalam satu baris sajak.

\section{b. Gaya Bahasa Asonansi bentuk pengulangan pola vokal yang sama dalam dua baris sajak dalam catatan harian Catatan Najwa}

Gaya bahasa asonansi menjadi bagian dari gaya bahasa yang berdasarkan langsung tidaknya makna. Gaya bahasa asonansi merupakan pengulangan pola vokal yang sama dalam dua baris sajak. Junus (1989: 215) mengatakan bahwa gaya bahasa asonansi merupakan perulangan kata dengan pola vokal yang sama pada dua baris sajak. Dalam penelitian ini penulis mengambil 5 kutipan dari 233 kutipan tersebut untuk dianalisis. Bentuk 5 kutipan gaya bahasa asonansi bentuk pengulangan vokal yang sama dalam satu kata dalam satu baris yang sama dalam catatan harian catatan najwa karya Najwa Shihab sebagai berikut:

1. Kita semua saudara sebangsa, dibesarkan zaman ditempa gelombang prahara.

2. Buat apa wilayah seluas Sabang sampai Merauke, jika pemudanya kehilangan idealisme .

3. Memang sedikit yang berani ambil risiko, lebih banyak yang memilih neko-neko.

4. Timur adalah tanah yang terus diberi janji, dan harapan yang tak pernah pasti.
5. Hari-hari penuh ketegangan dan bujuk rayu,

kita lalui dengan semangat serba baru.

Dalam kutipan (1) terdapat

bentuk gaya bahasa asonansi. Bentuk gaya bahasa asonansi di atas merupakan gaya bahasa asonansi dengan bentuk pengulangan pola vokal yang sama dalam dua baris sajak. Kalimat di atas dapat dianalisis dari penggunaan pola vokal yang sama dalam dua baris sajak. Pengulangan pola vokal /a/ dalam dua baris sajak tersebut, terdapat pada kata 'sebangsa' dalam baris pertama dan pada kata 'prahara' dalam baris kedua, yang memiliki pengulangan pola vokal yang sama yaitu tepat berada diakhir baris. Gaya bahasa asonansi dengan pengulangan pola vokal $/ a /$ dalam dua baris sajak tersebut sesuai dengan teori Junus (1989: 215) gaya bahasa asonansi merupakan perulangan kata dengan pola vokal yang sama pada dua baris sajak.

Pada kutipan (2) terdapat bentuk gaya bahasa asonansi. Bentuk gaya bahasa asonansi di atas merupakan gaya bahasa asonansi dengan bentuk pengulangan pola vokal yang sama dalam dua baris sajak. Pengulangan pola vokal le/ dalam dua baris sajak tersebut, terdapat pada kata 'merauke' dalam baris pertama dan pada kata 'idealisme' dalam baris kedua, yang memiliki pengulangan pola vokal yang sama yaitu tepat berada diakhir baris. Gaya bahasa asonansi dengan pengulangan pola vokal /e/ dalam dua baris sajak tersebut sesuai dengan teori Junus (1989: 215) gaya bahasa asonansi merupakan perulangan kata dengan pola vokal yang sama pada dua baris sajak.

Pada kutipan (3) terdapat bentuk gaya bahasa asonansi. Bentuk gaya bahasa asonansi di atas merupakan gaya bahasa asonansi dengan bentuk pengulangan pola vokal yang sama dalam dua baris sajak. Pengulangan pola vokal /o/ dalam dua baris sajak tersebut, 
terdapat pada kata 'risiko' dalam baris pertama dan pada kata 'neko-neko' dalam baris kedua, yang memiliki pengulangan pola vokal yang sama yaitu tepat berada diakhir baris, dan membentuk bunyi yang sama dari dua huruf terakhir yaitu ' $k o$ '. Gaya bahasa asonansi dengan pengulangan pola vokal /o/ dalam dua baris sajak tersebut sesuai dengan teori Junus (1989: 215) gaya bahasa asonansi merupakan perulangan kata dengan pola vokal yang sama pada dua baris sajak.

Pada kutipan (4) terdapat bentuk gaya bahasa asonansi. Bentuk gaya bahasa asonansi di atas merupakan gaya bahasa asonansi dengan bentuk pengulangan pola vokal yang sama dalam dua baris sajak. Pengulangan pola vokal /i/ dalam dua baris sajak tersebut, terdapat pada kata 'janji' dalam baris pertama dan pada kata 'pasti' dalam baris kedua, yang memiliki pengulangan pola vokal yang sama yaitu tepat berada diakhir baris. Gaya bahasa asonansi dengan pengulangan pola vokal / $i /$ dalam dua baris sajak tersebut sesuai dengan teori Junus (1989: 215) gaya bahasa asonansi merupakan perulangan kata dengan pola vokal yang sama pada dua baris sajak.

Pada kutipan (5) terdapat bentuk gaya bahasa asonansi. Bentuk gaya bahasa asonansi di atas merupakan gaya bahasa asonansi dengan bentuk pengulangan pola vokal yang sama dalam dua baris sajak. Pengulangan pola vokal $/ u /$ dalam dua baris sajak tersebut, terdapat pada kata 'pembaharu' dalam baris pertama dan pada kata 'meniru' dalam baris kedua, yang memiliki pengulangan pola vokal yang sama yaitu tepat berada diakhir baris, dan membentuk bunyi yang sama dari dua huruf terakhir yaitu ' $r \boldsymbol{u}$ '. Gaya bahasa asonansi dengan pengulangan pola vokal $/ u /$ dalam dua baris sajak tersebut sesuai dengan teori Junus (1989: 215) gaya bahasa asonansi merupakan perulangan kata dengan pola vokal yang sama pada dua baris sajak.

\section{c. Makna Kiasan Gaya Bahasa Asonansi dalam Catatan Najwa \\ Makna dalam bentuk kiasan} menjadi makna yang memiliki unsur keindahan, untuk mengkaji makna kiasan diperlukan terlebih dahulu memahami lebih dalam mengenai makna leksikal, untuk mengetahui makna sebenarnya. Makna kiasan menggunakan bahasa dengan makna yang bukan sebenarnya. Menurut (Chaer, 1990: 79) "Semua bentuk bahasa (baik kata, frase, maupun kalimat) yang tidak merujuk pada arti sebenarnya (arti leksikal, arti konseptual, atau arti denotatif) disebut mempunyai arti kiasan", yang sejalan pula dengan teori (Suwandi, 2011: 117) "Makna kiasan adalah pemakaian leksem dengan makna yang tidak sebenarnya". Makna leksikal merupakan makna yang bersifat leksem yaitu satuan bentuk bahasa yang bermakna, makna yang sesuai dengan referennya, atau makna yang sungguhsungguh nyata dalam kehidupan (Chaer, 1990: 62). Dalam penelitian ini penulis mengambil 5 kutipan dari 29 kutipan tersebut untuk dianalisis. Bentuk 5 kutipan makna kiasan dalam catatan harian Catatan Najwa karya Najwa Shihab sebagai berikut:

1. Tidak ada putra mahkota, semua warga punya hak setara.

2. Bekerja dengan tangan dan kaki sendiri, berkarya dengan memeras keringat sendiri.

3. Mereka hadapi persoalan rakyat kecil, dengan hasil rill lewat kerja-kerja detil.

Dalam kutipan (1) terdapat makna kias. Kutipan-kutipan di atas merupakan kutipan dengan bahasa yang memiliki makna bukan sebenarnya, yaitu dengan bahasa yang dikiaskan. Putra mahkota dalam kutipan tersebut termasuk ke dalam makna kiasan. Secara leksikal, menurut Kamus Besar Bahasa Indonesia, putra mahkota berarti seorang putra 
yang menggunakan mahkota. Indonesia bukan kerajaan, anak presiden bukan putri atau pangeran, sehingga dikatakan tidak ada putra mahkota yang bukan berarti putri yang memakai sebuah mahkota, tetapi berarti Indonesia tidak menggunakan keturunan dari seorang pemimpin untuk mendapatkan hak istimewa, tetapi semua warga Indonesia memilii hak yang sama, dan tidak ada bedanya, yang dikiaskan dengan tidak ada putra mahkota, sesuai dengan teori (Suwandi, 2011: 117) makna kiasan merupakan pemakaian leksem dengan makna bukan yang sebenarnya.

Pada kutipan (2) terdapat makna kias. Memeras keringat dalam kutipan tersebut termasuk ke dalam makna kiasan. Memeras keringat menurut Kamus Besar Bahasa Indonesia, berarti keringat yang diperas. Memeras keringat sendiri berdasarkan makna kiasan berarti bekerja dengan usaha sendiri, bekerja dengan sekuat tenaga, bekerja tanpa membawa nama orang tua, tetapi samasama berusaha seperti warga yang lain, sesuai dengan teori (Suwandi, 2011: 117) makna kiasan merupakan pemakaian leksem dengan makna bukan yang sebenarnya.

Pada kutipan (3) terdapat makna kias. Rakyat kecil dalam kutipan tersebut termasuk ke dalam makna kiasan. Secara leksikal, menurut Kamus Besar Bahasa Indonesia, berarti rakyat yang berbadan kecil. Secara kiasan, kutipan "Mereka hadapi persoalan rakyat kecil, dengan hasil rill lewat kerja-kerja detil" berarti mereka yaitu kepala daerah menghadapi persoalan rakyat yang berstatus sosial menengah kebawah dengan kerja yang detil. Status sosial yang menengah kebawah tersebut dikiaskan dengan sebutan rakyat kecil, sesuai dengan teori (Suwandi, 2011: 117) makna kiasan merupakan pemakaian leksem dengan makna bukan yang sebenarnya.

\section{SIMPULAN}

Berdasarkan analisis data yang telah dilakukan dalam penelitian ini, maka dapat dideskripsikan tiga hal terkait dengan hasil penelitian tugas akhir penulis yang berjudul Gaya Bahasa Asonansi dalam Catatan Harian Catatan Najwa Karya Najwa Shihab. Ketiga hal tersebut mencakup bentuk gaya bahasa asonansi dan makna kiasan. Adapun hasil analisis tersebut yaitu:

1. Bentuk gaya bahasa asonansi yang terdapat dalam catatan harian Catatan Najwa Karya Najwa Shihab meliputi gaya bahasa asonansi dengan pengulangan bunyi vokal dalam satu pengucapan bahasa dalam satu baris yang sama yaitu:

Kita semua saudara sebangsa

Berani bernegosiasi demi konsesi untuk negeri

Kami ragu karena semua sudah tahu. Dapat penulis simpulkan bahwa bentuk gaya bahasa asonansi dalam satu baris yang sama ditemukan dalam catatan harian Catatan Najwa karya Najwa Shihab yaitu dengan bunyi vokal $/ a /$, / $i /$, dan $/ u /$ yang ketika dibaca bunyi-bunyi tersebut akan menimbulkan efek keindahan

2. Gaya bahasa asonansi dengan pengulangan pola vokal yang sama dalam dua baris sajak yaitu:

Kita semua saudara sebangsa, dibesarkan zaman ditempa gelombang prahara

Buat apa wilayah seluas Sabang sampai Merauke,

jika pemudanya kehilangan idealisme Aroma rempah yang mengundang kononialisme,

derita panjang yang berujung nasionalisme, Memang sedikit yang berani ambil risiko,

lebih banyak yang memilih neko-neko Dapat penulis simpulkan bahwa bentuk gaya bahasa asonansi, dengan pengulangan pola vokal yang sama dalam dua baris sajak yaitu berarti 
pengulangan bunyi yang sama diakhir baris dalam satu baris pertama, dengan pengulangan bunyi yang sama diakhir baris pada baris kedua, sehingga akan terlihat dengan jelas bentuk pengulangan pola vokal tersebut dan terdengar indah. Gaya bahasa asonansi tersebut ditemukan dalam catatan harian Catatan Najwa karya Najwa Shihab yaitu dengan bunyi vokal $/ a /$, /el, /o/, /i/, dan /u/.

3. Makna kiasan yang terdapat dalam gaya bahasa asonansi dalam catatan harian Catatan Najwa Karya Najwa Shihab meliputi kata anak panah, uluran tangan, bukan barang baru, putra mahkota, memeras keringat sendiri, kasat mata, bumbu retorika, putra daerah, raja daerah, enggan turun tangan, dihisap, mandul, teriris, rakyat kecil, rekam jejak, berkecil hati, bintang iklan, ajang berjualan. Dari hasil penelitian, dapat penulis simpulkan bahwa makna kiasan ditulis dengan menggunakan bahasa pilihan, dan ditulis dengan menggunakan bahasa dengan makna yang bukan sebenarnya, yang harus diterjemahkan terlebih dahulu. Makna kias digunakan agar setiap bahasa yang disebutkan menjadi lebih halus, dan tidak terdengar kasar, dan menjadi lebih lembut dari arti yang sebenarnya.

\section{SARAN}

Penelitian ini bukanlah akhir dari penelitian tentang bentuk gaya bahasa asonansi dan makna kiasan. Oleh karena itu, penulis mengharapkan akan adanya penelitian lebih lanjut mengenai penggunaan bentuk gaya bahasa asonansi tentunya dengan analisis yang berbeda, supaya pengetahuan tentang gaya bahasa asonansi bisa semakin berkembang. Penulis sangat mengharapkan pada peneliti selanjutnya dapat meneliti tentang analisis catatan harian ini dengan metode lain atau dengan metode yang sama namun dengan permasalahan yang berbeda.

\section{DAFTAR PUSTAKA}

Achmad. (2012). Linguistik Umum. Jakarta: Erlangga.

Atmazaki. (2006). Kiat-kiat Mengarang dan Menyunting. Padang: Yayasan Citra Budaya Indonesia.

Emzir, dkk. (ed.). (2018). Tentang Sastra (Orkestrasi Teori dan Pembelajarannya). Yogyakarta: Garudhawaca.

Gunawan, E., Rahima, A., \& Supriyati, S. (2018). Analisis Tema ungkapan Tradisional Bapeno di Desa Hiang Kecamatan Sitinjau Laut Kabupaten Kerinci Provinsi. Aksara: Jurnal Ilmiah Pendidikan Bahasa dan Sastra Indonesia, 2(1), 130-141.

Ismawati, Esti. (2013). Pengajaran Sastra. Yogyakarta: Ombak.

Junus, Umar. (1989). Stilisika Suatu Pengantar. Ampang:

Dewan Bahasa dan Pustaka.

Keraf, Gorys. (1984). Diksi dan Gaya Bahasa. Jakarta: PT Gramedia.

Moleong, Lexy, J. (2009). Metodologi Penelitian Kualitatif. Bandung: Remaja Rosdakarya.

Muhammad. (2011). Metode Penelitian Bahasa. Jogjakarta: ArRuzz Media.

Parera, J. D. (1991). Teori Semantik. Jakarta: $\quad$ Erlangga.

Rahima, A. (2017). Literature Reception (a Conceptual Overview). Jurnal Ilmiah Dikdaya, 6(1), 1-16.

Ratna, Nyoman Khuta (2017). Estetika Sastra dan Budaya. Yogyakarta: Pustaka Pelajar. 
Shihab, Najwa. (2017). Catatan Najwa.

Ciputat: Literati.

Sugiyono. (2007). Metode Penelitian

Pendidikan (Pendekatan

Kuantitatif, Kualitatif dan

$R \& D)$. Bandung: $\quad$ Alfabeta. 